\title{
Refractory Status Asthmaticus: A Case for Unconventional Therapies
}

\author{
Rohit Vohra, Anil Sachdev', Dhiren Gupta, Neeraj Gupta, Suresh Gupta \\ Department of Pediatric Emergency and Critical Care Unit, Institute of Child Health, ${ }^{1}$ Department of Child Health, Sir Ganga Ram Hospital, New Delhi, India
}

\section{Abstract}

Status Asthmaticus is a common reason for Emergency Room visits in children. Most of the asthma flares are successfully managed by use of $\beta$ agonist and steroids. If these therapies fail to halt the progression of asthma, a number of medical therapies may be used to treat it. However, the data supporting the use of these therapies are conflicting. We present successful use of Extracorporeal Membrane Oxygenation and isoflurane in a child with Refractory Status Asthmaticus.

Keywords: Extracorporeal membrane oxygenation, isoflurane, status asthmaticus

\section{INTRODUCTION}

Asthma is an immune-mediated process in which an environmental or infectious agent triggers a hypersensitivity immunoglobulin E-mediated allergic response, is triggered by an environmental agent leading to mast cell degranulation, histamine release, and activation of pro-inflammatory cytokines. ${ }^{[1]}$ Acute exacerbation of asthma is a common reason for Emergency Room visits in children. If initial management fail to control the progression of asthma episode, children may require admission in intensive care unit. Following the initial therapy with inhaled $\beta 2$ agonists and systemic corticosteroids, a wide array of adjunct medical therapies has been used in the management of status asthmaticus (SA). Unfortunately, the data supporting the use of these adjunct therapies are conflicting, or absent, Extracorporeal membrane oxygenation (ECMO) and inhaled anaesthetic agents have been used with varying success in children with SA not responsive to conventional treatment. Here we report successful use of ECMO and isoflurane in a $6 \frac{1}{2}$ year male child with refractory SA.

\section{Case Report}

A $61 / 2$-year-old male child presented with a history of cough and cold for 5 days and rapid breathing for the past $5 \mathrm{~h}$. The child was a diagnosed case of mild persistent asthma for the past 3 years and was on intermittent therapy with inhaled steroids and $\beta 2$ agonists. There was no history of allergy or

\begin{tabular}{|l|l|}
\hline \multicolumn{3}{|c|}{ Access this article online } \\
\hline Quick Response Code: & Website: \\
\hline & www.ijccm.org \\
\cline { 2 - 2 } & \\
\hline
\end{tabular}

asthma in other family members. There was no history of hospitalization for acute asthma or any other illness.

The child was taken to a private hospital where, at presentation, he was found to be in respiratory failure with RR $60 / \mathrm{min}$, oxygen saturation $\left(\mathrm{SpO}_{2}\right)$ of $77 \%$ with marked chest retractions, and bilateral diminished air entry in lungs. He was started on oxygen inhalation, continuous nebulization with $\beta 2$ agonist, and intravenous magnesium sulfate. However, the child's condition did not improve, and arterial blood gas ( $\mathrm{ABG}$ ) analysis done after 30 min of treatment revealed $\mathrm{pH} 7.1, \mathrm{PCO}_{2} 90 \mathrm{mmHg}$, $\mathrm{PO}_{2} 120 \mathrm{mmHg}$, and $\mathrm{HCO}_{3} 28 \mathrm{mmol} / \mathrm{L}$ (partial compensated respiratory acidosis). The child was intubated via orotracheal route with a 5.5-mm size cuffed endotracheal tube and started with pressure-regulated volume control (PRVC) mode. In view of high peak inspiratory pressure (PIP $70 \mathrm{cmH}_{2} \mathrm{O}$ ) required to ventilate, the patient was shifted to our facility on bag and tube ventilation.

On admission, the child had heart rate of $150 / \mathrm{min}$, blood pressure of $130 / 80 \mathrm{mmHg}$ (more than $99^{\text {th }}$ centile for age, sex, and height), and $\mathrm{SpO}_{2} 96 \%$ on bag and tube ventilation. The child was started on PRVC mode with tidal volume

Address for correspondence: Dr. Anil Sachdev, Department of Child Health, Sir Ganga Ram Hospital, Old Rajinder Nagar, New Delhi - 110 060, India. E-mail: anilcriticare@gmail.com

This is an open access journal, and articles are distributed under the terms of the Creative Commons Attribution-NonCommercial-ShareAlike 4.0 License, which allows others to remix, tweak, and build upon the work non-commercially, as long as appropriate credit is given and the new creations are licensed under the identical terms.

For reprints contact: reprints@medknow.com

How to cite this article: Vohra R, Sachdev A, Gupta D, Gupta N, Gupta S. Refractory status asthmaticus: A case for unconventional therapies. Indian J Crit Care Med 2018;22:749-52. 
(Vt) $8 \mathrm{ml} / \mathrm{kg}$, frequency $20 / \mathrm{min}$, and $\mathrm{FiO}_{2} 0.5$ positive end-expiratory pressure (PEEP) zero. On these settings, the child had an auto-PEEP of $12 \mathrm{cmH}_{2} \mathrm{O}$ with PIP of $45 \mathrm{mmHg}$ and transairway pressure of $28 \mathrm{cmH}_{2} \mathrm{O}$. ABG analysis revealed $\mathrm{pH} 6.8, \mathrm{PCO}_{2} 184 \mathrm{mmHg}, \mathrm{PO}_{2} 115 \mathrm{mmHg}$, and $\mathrm{HCO}_{3} 24 \mathrm{mmol} / \mathrm{L}$. Chest radiograph showed bilateral hyperinflated lungs [Figure 1]. Aerosol therapy with salbutamol $(2.5 \mathrm{mg})$, ipratropium bromide $(250 \mu \mathrm{g})$ using in-line nebulization system (Aeroneb Solo, Aerogen Ltd, Galway, Ireland), intravenous methylprednisolone ( $2 \mathrm{mg} / \mathrm{kg})$, ketamine $(1 \mathrm{mg} / \mathrm{kg} / \mathrm{h})$, magnesium sulfate $(50 \mathrm{mg} / \mathrm{kg})$, and aminophylline $(0.9 \mathrm{mg} / \mathrm{kg} / \mathrm{h})$ infusions was started. In view of the persistent respiratory acidosis, emergency bedside flexible fiberoptic bronchoscopy was done to clear retained secretions. However, with $\mathrm{pH}$ remaining $<7$ and $\mathrm{PCO}_{2}$ above $130 \mathrm{mmHg}$, the child was initiated on venovenous ECMO after $8 \mathrm{~h}$ of admission. The left femoral vein and the right internal jugular vein were cannulated using $17 \mathrm{Fr}$ and 21 Fr Biomedicus (Medtronic, Grand Rapids, Minnesota, USA) ECMO cannulas by the pediatric cardiothoracic team [Figure 2]. The patient was kept at $100 \%$ flow rate according to body surface area with $\mathrm{FiO}_{2} 0.4$ and sweep gas flow of $1 \mathrm{~L} / \mathrm{min}$. The $\mathrm{ABG}$ normalized after $40 \mathrm{~min}$ of starting ECMO (pH 7.43, $\mathrm{PCO}_{2} 38.2 \mathrm{mmHg}$, $\mathrm{PO}_{2} 150 \mathrm{mmHg}$, and $\mathrm{HCO}_{3} 25.2 \mathrm{mmol} / \mathrm{L}$ ).

While on ECMO support, resting lung ventilation was continued with volume-controlled mode (frequency $15 / \mathrm{min}, \mathrm{Vt}$ $6 \mathrm{ml} / \mathrm{kg}, \mathrm{FiO}_{2}$ 0.4, and PEEP zero). Nebulization with $\beta$-agonist and intravenous ketamine infusion were continued. His cerebral oxygenation was monitored by near-infrared spectroscopy with values maintained around $60 \%-70 \%$. He continued to have severe bronchospasm with transairway pressures of around $35 \mathrm{cmH}_{2} \mathrm{O}$ and auto-PEEP of $10 \mathrm{cmH}_{2} \mathrm{O}$. The child could not be weaned off even after $36 \mathrm{~h}$ of institution of ECMO, so was started on inhalation anesthetic isoflurane. Isoflurane was given by a Drager Primus ventilator (MIBII PROTO CONV-LS) to maintain end-expiratory concentration of $1.2 \%$. To prevent exposure of gas to other patients and health-care professionals, isoflurane was given in a special isolation room. Bronchospasm

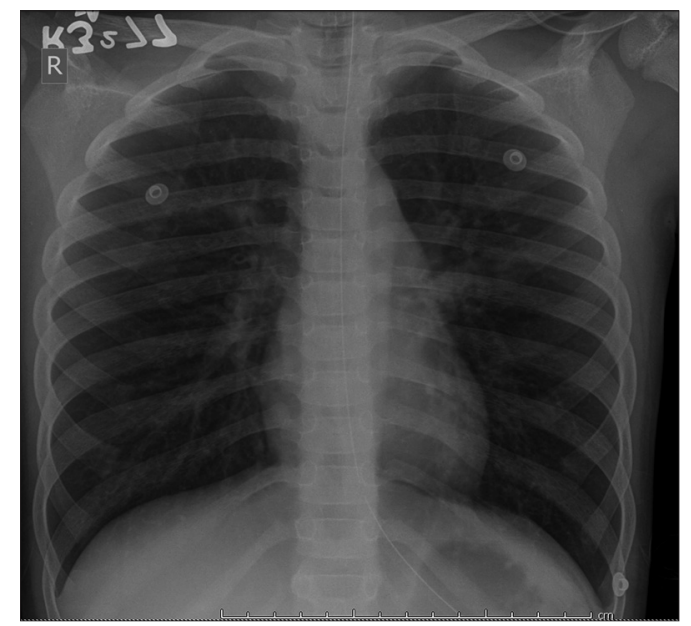

Figure 1: Chest X-ray at admission improved within $8 \mathrm{~h}$ of starting isoflurane, auto-PEEP decreased to $2 \mathrm{cmH}_{2} \mathrm{O}$, transairway pressure decreased to 10 $\mathrm{cmH}_{2} \mathrm{O}$ [Figure 3], and air entry in both lungs also improved. He developed hypotension requiring norepinephrine infusion $(0.05$ $\mu \mathrm{g} / \mathrm{kg} / \mathrm{min}$ ). The child was successfully weaned off ECMO $12 \mathrm{~h}$ after starting isoflurane. Isoflurane was also tapered to $0.3 \%$ and subsequently stopped after $6 \mathrm{~h}$ of ECMO discontinuation. He was extubated on day 6 of admission and discharged from the hospital on inhaled corticosteroids and $\beta 2$ agonists on day 10 of hospitalization with no neurological sequelae.

\section{Discussion}

Asthma is an inflammatory disorder of the airways characterized by airway hyperactivity with bronchospasm, mucosal swelling, and mucus production. SA, also known as acute severe asthma, is a condition of progressively worsening bronchospasm and respiratory dysfunction due to asthma, which is unresponsive to standard conventional therapy and may progress to respiratory failure and the need for mechanical ventilation. ${ }^{[2]}$ Asthma is a serious public health problem, especially in children. The World Health Organization estimates that 300 million individuals worldwide suffer from asthma. A further increase in 400 million is expected by 2025 owing in part to increasing industrialization and pollution in urban areas. ${ }^{[3]}$ Children are at greater risk with $9.6 \%$ compared to $7.7 \%$ adults. ${ }^{[4]}$

$\beta 2$ agonists and steroids are the mainstay of treatment causing bronchodilation and anti-inflammatory effects. ${ }^{[5]}$ Other available adjunct therapies including anticholinergics, magnesium sulfate, methylxanthines, ketamine, and heliox have been utilized with varying results. ${ }^{[6]}$

In situations of refractory SA not responding to adjunctive therapies, inhaled anesthetic gases such as isoflurane, halothane, and sevoflurane are alternatives to enhance bronchodilation $^{[7]}$ [Figure 4]. There are several proposed mechanisms of action for inhaled anesthetic gases including beta-adrenergic receptor activation, direct bronchial smooth muscle relaxation by inhibition of acetylcholine and histamine,

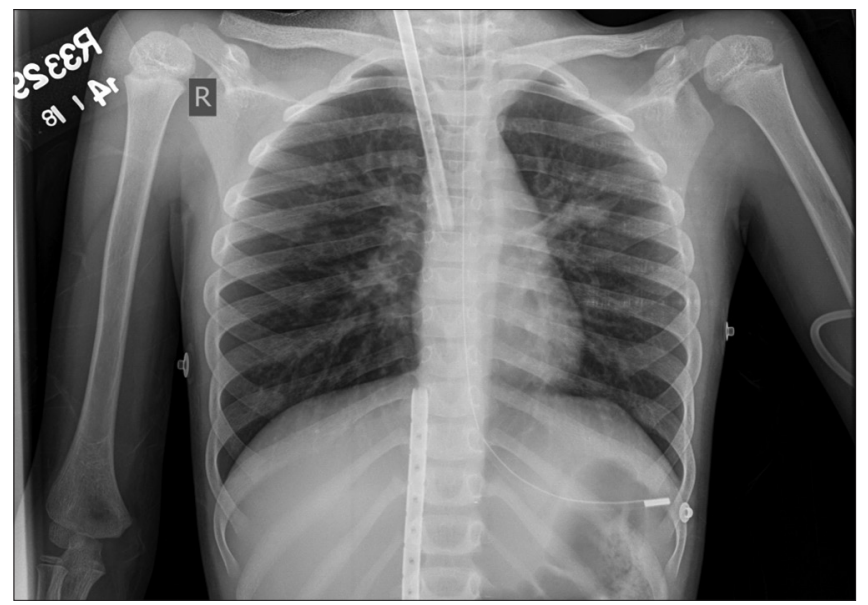

Figure 2: X-ray showing extracorporeal membrane oxygenation cannulas in situ 


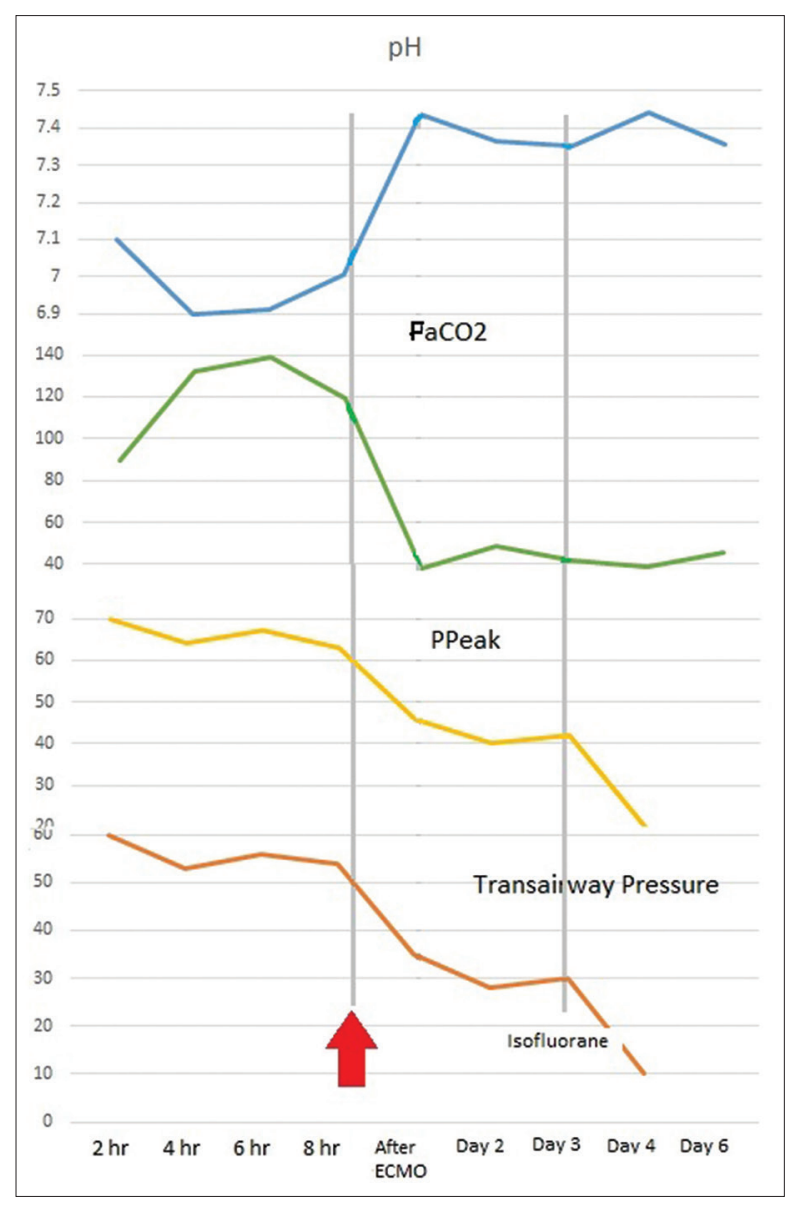

Figure 3: Line diagram showing trends of $\mathrm{pH}, \mathrm{PCO}_{2}$, PPeak, and transairway pressures

and hindrance of hypocapnic bronchoconstriction ${ }^{[8]}$ Isoflurane and sevoflurane are most commonly used, as halothane may cause severe hepatotoxicity, particularly with prolonged use. The most common adverse effect of these gases is vasodilation resulting in hypotension. In our patient, hypotension occurred with isoflurane, which was managed with norepinephrine. Turner et al.${ }^{[9]}$ used isoflurane in 31 children over 15 years and reported improvement in $\mathrm{pH}$ and $\mathrm{PCO}_{2}$ within $4 \mathrm{~h}$ of initiation. Inhaled anesthetics are usually used as a rescue therapy in patients of SA due to the high cost and potential for adverse effects. Using inhaled anesthetics outside of the operating room remains challenging as it requires specialized equipment to prevent release of the active gas into the environment and resulting in unintentional exposure to health-care professionals and other patients. ${ }^{[10]}$

When the clinical goals of treatment of SA are not achieved using the appropriate invasive ventilation strategy and intensive medical treatment, ECMO is a modality that may be considered to support gas exchange ${ }^{[11]}$ [Figure 4]. Venovenous ECMO is generally the preferred approach for patients with asthma requiring ECMO. ${ }^{[12]}$

Multiple case reports describe successful use of ECMO for refractory SA. Hebbar et al. ${ }^{[13]}$ reported the use of ECMO

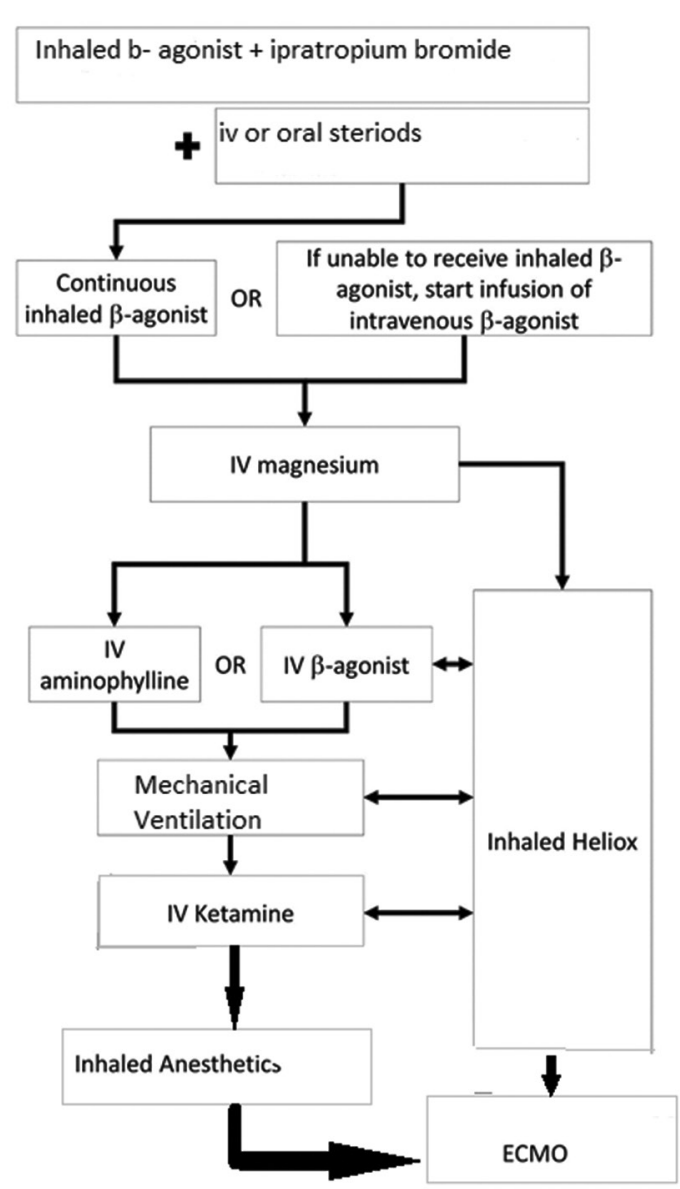

Figure 4: Flowchart showing the use of advanced therapies in case of status asthmaticus

in 13 children for refractory SA from 1986 to 2007. All patients received aggressive use of medical and anesthetic therapies for SA before initiation of ECMO with a median $\mathrm{PaCO}_{2}$ of $130 \mathrm{mmHg}$ (range $102-186 \mathrm{mmHg}$ ) and blood pH 6.89 (range 6.75-7.03). Venovenous ECMO was used in 12 patients while venoarterial ECMO was used in one patient. Median time spent on ECMO was $95 \mathrm{~h}$ (range 42-395 h). One patient developed pulmonary hemorrhage and pneumothorax occurred in 2 of 13 (15\%). All 13 children survived without neurological sequelae.

Inhaled anesthetics such as isoflurane can be used in life-threatening SA not responding to conventional treatment before instituting ECMO. However, in certain emergency circumstances like in our patient who had blood pH 6.8 and $\mathrm{PCO}_{2} 184 \mathrm{mmHg}$ which were incompatible with life, instituting early ECMO can be lifesaving as anesthetic gases may take up to $12 \mathrm{~h}$ for therapeutic response. ${ }^{[11]}$

\section{Conclusion}

When some patients of severe asthma failed to respond with conventional treatment, inhaled anesthetics such as isoflurane and ECMO can be lifesaving. 


\section{Declaration of patient consent}

The authors certify that they have obtained all appropriate patient consent forms. In the form the patient(s) has/have given his/her/their consent for his/her/their images and other clinical information to be reported in the journal. The patients understand that their names and initials will not be published and due efforts will be made to conceal their identity, but anonymity cannot be guaranteed.

\section{Financial support and sponsorship \\ Nil.}

\section{Conflicts of interest}

There are no conflicts of interest.

\section{RefEREnCES}

1. National Asthma Education and Prevention Program. Expert panel report 3 (EPR-3): Guidelines for the diagnosis and management of asthma-summary report 2007. J Allergy Clin Immunol 2007;120:S94-138.

2. Afzal M, Tharratt RS. Mechanical ventilation in severe asthma. Clin Rev Allergy Immunol 2001;20:385-97.

3. Masoli M, Fabian D, Holt S, Beasley R, Global Initiative for Asthma (GINA) Program. The global burden of asthma: Executive summary of the GINA Dissemination Committee Report. Allergy 2004;59:469-78.
4. Moorman JE, Akinbami LJ, Bailey CM, Zahran HS, King ME, Johnson CA, et al. National surveillance of asthma: United States, 2001-2010. Vital Health Stat 3 2012;35:1-58.

5. Tan KS, McFarlane LC, Lipworth BJ. Effects of oral and inhaled corticosteroid on lymphocyte beta2-adrenoceptor function in asthmatic patients. Br J Clin Pharmacol 1997; 44:565-8.

6. Wong JJ, Lee JH, Turner DA, Rehder KJ. A review of the use of adjunctive therapies in severe acute asthma exacerbation in critically ill children. Expert Rev Respir Med 2014;8:423-41.

7. Char DS, Ibsen LM, Ramamoorthy C, Bratton SL. Volatile anesthetic rescue therapy in children with acute asthma: Innovative but costly or just costly? Pediatr Crit Care Med 2013;14:343-50.

8. Carrié S, Anderson TA. Volatile anesthetics for status asthmaticus in pediatric patients: A comprehensive review and case series. Paediatr Anaesth 2015;25:460-7.

9. Turner DA, Heitz D, Cooper MK, Smith PB, Arnold JH, Bateman ST, et al. Isoflurane for life-threatening bronchospasm: A 15-year single-center experience. Respir Care 2012;57:1857-64.

10. Tobias JD. Therapeutic applications and uses of inhalational anesthesia in the pediatric Intensive Care Unit. Pediatr Crit Care Med 2008;9:169-79.

11. Rehder KJ. Adjunct therapies for refractory status asthmaticus in children. Respir Care 2017;62:849-65.

12. Rehder KJ, Turner DA, Bonadonna D, Walczak RJ Jr., Cheifetz IM State of the art: Strategies for extracorporeal membrane oxygenation in respiratory failure. Expert Rev Respir Med 2012;6:513-21.

13. Hebbar KB, Petrillo-Albarano T, Coto-Puckett W, Heard M, Rycus PT, Fortenberry JD, et al. Experience with use of extracorporeal life support for severe refractory status asthmaticus in children. Crit Care 2009;13:R29. 